\title{
Zika a Big Concern to the Recent World
}

\author{
Naheed Afshan Irfan*, Maham Ghouri and Aliya Hayat \\ ${ }^{1}$ Department of Microbiology, Jinnah University for Women, Karachi, Pakistan.
}

\begin{abstract}
ZIKV is the most promising mosquito borne Arbovirus infection. Aedes mosquitoes are responsible for causing this disease. About $80 \%$ of infections are asymptomatic. Our aim is to get an overview about the epidemics of ZIKV infections throughout the years from the first case in Uganda whyich occurred in 1947 till now. Studies reveal that the disease occurs from being mild to severer with complications like microcephaly, fetal malformations and Guillain-Barre syndrome (GBS). It arises from the regions of Africa, Nigeria, Sierra, Leone, and Gabon. Diagnosis occurs through PCR; Zika viruses can cross-react with other flaviviruses. There are various factors that are vague regarding the Pathogenicity of ZIKV. No medication and vaccine are available for treating Zika virus infection. Vaccine of Zika is expected to arrive soon. If the modern procedures are followed and chased appropriately it could lead to the control of this infection.
\end{abstract}

Keywords: Autoimmune disorder, Guillain-Barre syndrome, pathogenicity, Arboviruses, Self-limiting fever, Zika virus.

doi.org/10.21089/njhs.21.0031

\section{INTRODUCTION}

Zika virus (ZIKV) is placed in group of Flaviviridae viruses. The causative agent of ZIKV is Flavivirus which is also associated with yellow fever, dengue fever, Japanese encephalitis and West Nile viruses. The first out break of ZIKV was spot farther from Africa and Asia in the year 2007, on the Yap Island in the Southwestern Pacific Ocean. ZIKV emerges with different symptoms like rash, arthralgia, and conjunctivitis. The information related to disease history, mode of transmission, virology, and clinical evidence helped in distinguishing between ZIKV and dengue fever. The studies conducted in 1968 and during the period of 1971-1975 revealed that the Nigerian population was mostly suffering from ZIKV. One study showed that $40 \%$ of people had antibodies against ZIKA. These were obtained from pyretic children of 10 months, 2 years and 3 years of age [1,2]. Arboviruses can be deliberated as the risk to the worldwide health in the up and coming days. The pathogens from this group are responsible for causing vector born diseases and able to arrive and spread selectively to the new geographical locations. Most humans are reservoirs for this disease. Mostly people from urban population suffer from such disease, but it may become a hazardous and troublesome epidemic if a new population gets exposed [3].

Spread of Zika virus: After the outbreak quick hazard evaluations were taken place, from 1960 to 1980 , it is revealed that eight novel countries were endemic which included:

*Address correspondence to this author at Jinnah University for Women, Department of Microbiology Karachi, Pakistan.

E-mail: naheedafshan7@hotmail.com
American Samoa, Costa Rica, Curaçao, Dominican Republic, Jamaica, Nicaragua, Tonga and US Virgin Islands [4]. The outbreak carried on progressing hastily in the Americas and spreading to new countries and states in the Caribbean and Central America. There are about thirty five states that have been reported endemic of ZIKV in the last nine months. In Colombia regarding the Zika virus disease in a 15 year old girl suffering from sickle cell disease (SCD) has raised another query if SCD is a source of Zika virus illness, since it is famous for its association with severe dengue and Chikungunya [5].

The first statement regarding the association of Zika disease and sickle cell disease was revealed by this study. As current cases are rising in the districts where sickle cell disorders are already existing (like Caribbean), Zika disease interpretation must be examined more within those patients. The local health authorities in Texas, US, on $2^{\text {nd }}$ February 2016 announced an authentic case of sexually transmitted Zika virus disease [6], which is supposed to be recognized as the second case of sexual transmission to date [7]. Their susceptibility to develop and settle in different geographic states arise health related risks and analytical difficulties. Asia has been considered as a core for the spread of numerous arboviruses.

Clinical Senario of Zika virus: Zika virus transmitted through a RNA virus that passes to other people by the mosquitoe Aedes aegypti species. 80\% of infections are asymptomatic. Clinical forms ranges from asymptomatic stage, which includes influenza- like symptoms that include fever, headache, depression, and cutaneous rash. [8]. Symptomatic stage comprises of self-limiting fever for 4 to 7 days' 
duration followed by maculopapular rash, arthralgia, conjunctivitis, myalgia and headache. In previous years the Zika virus has not been recognized for the cause of increase mortality rate, nor related to the intrauterine infections and congenital CNS anomalies. In the year 2004 for the first time the connection between Zika virus and GBS was revealed during an epidemic in French Polynesia [9]. There is no preventive measure against Zika virus infection because there is no vaccine and any antiviral drug available. This virus can be confirmed by RNA or classification of exact antigenic determinants from patient's sera. Antibodies can be detected from 5 to 6 days after the exposure. Serological results must be notified carefully as antibodies may cross react with other flavivirus like dengue.

Genetics: Different studies on the virulence of ZIKV revealed that it is a SS-RNA virus with 10,794 nucleotides that encodes for three structural and five non-structural genes [10], nucleotides that are adjoining with 2 noncoding regions (59 and NCR) and only extended chain of polyprotien openly read from: 59-C-prM-E-NS1-NS2A-NS2BNS3-NS4ANS4B-NS5-39, the frame will cleave into capsid (C), originator of membrane (perm), envelope (E) and seven non structural groups of proteins (NS) [11]. The E protein $(<53 \mathrm{kDa})$ is the main virulent surface protein that is playing an important role in the viral replication, mediating binding and blending of membranes [12].

These are responsible for coding 3,419 amino acids It is strictly linked towards the Spondweni virus, the other members of the Spondweni cloude within the mosquito borne flaviviruses. These two viruses are representatives of their faces which are responsible for the mosquito-borne illness by the group of flavivirus $[10,13,14]$.

There appear to be three families of ZIKV based on NS5 homology - the East-African lineage, a West-African ancestry, and the more distally related Yap ancestry. [10] Just two complete genome sequences of ZIKV published in GenBank, the archetype MR766, confined from the rhesus monkey 766 in the forest of Zika in 1947 and ZIKA EC in 2007, which was accomplished from the occurrence, a rise in Yap. Sequence similarity observed $89 \%$ homology with the $97 \%$ of the amino acid. The selected target gene for the primers was NS5. The sequences of MR766 (GenBank accession number AY632535.2) and ZIKA EC 2007 (GenBank accession number EU545988.1) were observed by using Clustal W software .Internal core (IC) primers act on glyceraldehyde-3phosphate dehydrogenase (GAPDH), it is considered as a human housekeeping gene, which was preferred to manage any possible sample for the inhibition of the PCR reaction. No cross-reactivity was observed by the primers other than their selective markers in the BLAST database. The pairs of primer sequences, its meditation and cycling position that were used in a single reaction were vigilantly done to de- crease the probability configuration within the Secondary structures and other spirited reticence between the primers. Most favorable primer combinations must be selected for each set of primers by the titration of primers experimentally and the best annealing temperature was resolved by the rise of temperature [15].

The biggest viral protein is NS5 with $<103 \mathrm{KDa}$ molecular weight whose C-terminal portion carries RNA-dependent RNA polymerase (RdRP) action and the N-terminal occupied RNA capping asset dispensation due to action of methyl transferase [12]. The 39NCR genome of ZIKV consists of 428 nucleotides, that carry out 27 ruin patterns [16], thus plays its role in the cellular and specific hyper-immunity in vivo within the mouse ascitic fluid [17]. For genomic studies Cultures supernatants were collected for isolation of viral RNA. Viral elements, translations, genetic balance, RNA packaging, or cyclization [12]. Even though various researches have also played important role to compassionate the revolutionary biology of flaviviruses universally [18] only some studies have dispatched revolution of ZIKV [19]. All the researches revealed three main sources of ZIKV, one from Asia to Africa. The main purpose is to captivate this difference to achieve exceptional observations regarding ZIKV genetic progression. In the $20^{\text {th }}$ century 43 strains of ZIKV were studied, that were obtained from 1947 to 2007 in Africa and Asia. All studies express phyletic relations, discriminating consequences, recombination occasions, phylodynamics, phylogeography, host relations with viral origins and glycosylation patterns [20].

\section{EPIDEMIOLOGY}

First Zika virus was isolated from a guard rhesus monkey from the Zika Forest of Uganda in 1947 [21], and after that it has been isolated from the African mosquito species, Aedes africanus, collected in Uganda [21] and in the Central African Republic [22] from Ae. Luteocephalus and Ae. spp in Nigeria [23]. The virus has also been isolated in Malaysia from Ae. Aegypti [24]. It has been confirmed serologically that ZIKA affects the person by neutralizing antibodies in inhabitants of Uganda [21, 25]. In the same way, it can spread through direct contact between two people, most likely during sexual contact [7]. After the discovery of ZIKV in Uganda from group of A. Africans mosquitoes [21] after that the sociological and epidemiological analysis showed that ZIKV illness in the continent of Africa, in Nigeria in 1971 and 1975 [26], Sierra Leone in 1972 [27]. Gabon in 1975 [27] Uganda in 1969 and 1970 [28], Central African Republic in 1979 [29], Senegal from 1988 to 1991 [30] and Co^te D'Ivoire in 1999 [31]. As of late, ZIKV was recognized in Senegal in 2011 and 2012. Likewise, ZIKV diseases in Asia were accounted for in Pakistan [32], Malaysia [24], Indonesia in 1977 and 1978 [33], Micronesia in 2007 [34] and Cambodia in 2010 [11]. Even though ZIKV was constantly 
isolated, in 2007, 49 cases were reported, out of which $73 \%$ were older than 3 years and were diagnosed serologically when the infection spread towards the Yap island in Micronesia. This gives confirmation about ZIKV illness [34]. The incidences of Zika Fever (ZF) can be confused with the dengue fever, that was happening on the start of the Micronesian outbreak [34].

There was no spread of ZIKV observed in the Pacific before 2013. French Polynesia (FP) disclosed the very first case and later on a consecutive hazardous epidemic arose with probably 28,000 cases looking for medical care (about $11 \%$ of total population). Genetic investigations indicated that the FP strain was strongly linked to Cambodia 2010 and Yap State 2007 strains [19].Throughout the FP epidemic, the majority of cases had the same symptoms of mild disease characterized by low-grade fever, arthralgia, maculopapular rash and conjunctivitis. In November, a patient was observed with the Guillain-Barre syndrome (GBS), which is an autoimmune disease that generates acute or sub acute flaccid paralysis, after one week exposure to acute ZIKV illness [35]. Consequently, more cases of GBS were determined, with the ZIKV epidemic. In February 2016, infection started spreading towards America. WHO confirmed that ZIKV disease is linked with the microcephaly and other neurological ataxia and established a Public Health Emergency of International Center (PHEIC).

\section{RESCENT EVENTS}

An endemic was reported in the states of Bahia and Rio Grande do Norte in Brazil on May 2015 [36]. Yet it is possible that the Zika virus had been spread in Salvador de Bahia City before the illness was observed between 15 February and 25 June 2015. In March 2015 about 10 cases were reported in Camaçari, Salvador Metropolitan Region, state of Bahia [37, 38]. From October 2015, there was an increase in cases of microcephaly in the state of Pernambuco in Brazil, according to the Brazilian live birth information system (SINASC) which analyzed significant increase in the total reported cases of microcephaly in comparison with the past years in different states of Brazil [39]. An epidemiological report on neurological disorders, hereditary aberrations and Zika virus disease had been delivered on 17 January 2016, by the Pan American Health Organization/World Health Organization (PAHO/WHO) [40]. The spread of Zika virus was recognized by the PAHO/WHO in different countries of South/Central America and in the Caribbean. PAHO/WHO mentioned that their associate states: 'establish and maintain the capacity to detect and confirm Zika virus cases, prepare health care facilities to respond to a possible increased demand of specialized care for neurological syndromes, as well as to strengthen antenatal care'.

The Emergency Committee had been gathered by the Director-General of WHO on $1^{\text {st }}$ February 2016 to determine community health consequences of an array of microcephaly incidences and neurological syndromes. The board featured the value of extents to minimize Zika virus illness, mainly within pregnant women, must have to develop steady examination for microcephaly and GBS. Furthermore, the Emergency Committee accentuates the requirements for modern study of the etiology of the new batch of microcephaly and other neurological ailments with the evaluation of fundamental association between the Zika virus and other potential risk factors or co-factors. In the conclusion of the emergency Committee "The WHO Director-General said that a causal association between Zika illness amid pregnancy and microcephaly is unequivocally suspected, however, it is not experimentally established" [41].

\section{ACKNOWLEDGEMENT}

Declared none.

\section{CONFLICT OF INTEREST}

Declared none.

\section{REFERENCES}

[1] Moore DL, Causey OR, Carey DE, Reddy S, Cooke AR, Akinkugbe FM, et al., Arthropod-borne viral infections of man in Nigeria, 1964-1970. Ann. Trop. Med. Parasitol., 1975; 69: 49-64.

[2] Fagbami A. Epidemiological investigations on arbovirus infections at Igbo-Ora, Nigeria. Trop. Geographical Med., 1977; 29(2), 187191.

[3] Weaver, S.C. and Reisen, W.K., Present and future arboviral threats. Antiviral Res., 2010; 85(2), 328-345.

[4] European centre for disease prevention and control rapid risk assessment zika virus disease epidemic: pptential association with microcephaly and guillan-Barrie syndrome second update, 8th February 2016. Stockholm: ECDC; 2016.

[5] Arzuza-Ortega, L., Polo, A., Pérez-Tatis, G., López-García, H., Parra, E. and Pardo-Herrera, L.C., 2016. Fatal sickle cell disease and Zika virus infection in girl from Colombia. Emerg Infect. Dis.

[6] Hajra, A., Bandyopadhyay, D. and Hajra, S.K. Zika virus: A global threat to humanity: A comprehensive review and current developments. N. Am. J. Med. Sci., 2016; 8(3): 123.

[7] Robin, Y. and Mouchet, J., [Serological and entomological study on yellow fever in Sierra Leone]. Bulletin de la Societe de Pathologie Exotique et de ses Filiales, 1974; 68(3): 249-258.

[8] Foy, B.D., Kobylinski, K.C., Chilson Foy, J.L., Blitvich, B.J. Travassos da Rosa, A., Haddow, A.D., Lanciotti, R.S. and Tesh, R.B. Probable non-vector-borne transmission of Zika virus, Colorado, USA. Emerg. Infect. Dis., 2011; 17(5): 880-2.

[9] Lanciotti, R.S., Kosoy, O.L., Laven, J.J., Velez, J.O., Lambert, A.J., Johnson, A.J., Stanfield, S.M. and Duffy, M.R., 2008. Genetic and serologic properties of Zika virus associated with an epidemic, Yap State, Micronesia. Emerg. Infect. Dis., 2007; 14(8): 1232-9.

[10] Kuno, G., Chang, G.J.J., Tsuchiya, K.R., Karabatsos, N. and Cropp, C.B. Phylogeny of the genus Flavivirus. J. Virology, 1998; 72(1): 73-83.

[11] Heang, V., Yasuda, C.Y., Sovann, L., Haddow, A.D., Travassos da Rosa, A.P., Tesh, R.B. and Kasper, M.R., 2012. Zika virus infection, Cambodia. Emerg. Infect. Dis., 2010; 18(2:), 349-51. 
[12] Lindenbach, B.D. and Rice, C.M. Molecular biology of flaviviruses. Advances in virus research, 2003; 59: 23-62.

[13] Cook, S. and Holmes, E.C. A multigene analysis of the phylogenetic relationships among the flaviviruses (Family: Flaviviridae) and the evolution of vector transmission. Archives of virology, 2006; 151(2): 309-325.

[14] Simpson DI. Zika virus infection in man. Trans. R. Soc. Trop. Med. Hyg., 1964; 58: 335-338.

[15] Mackenzie, J.S. and Williams, D.T. The zoonotic flaviviruses of Southern, South-Eastern and Eastern Asia, and australasia: the potential for emergent viruses. Zoonoses and public health, 2009; 56(67); 338-356.

[16] Kuno, G. and Chang, G.J. Full-length sequencing and genomic characterization of Bagaza, Kedougou, and Zika viruses. Archives of virology, 2007; 152(4): 687-696.

[17] Digoutte, J.P., Calvo-Wilson, M.A., Mondo, M., Traore-Lamizana, M. and Adam, F., Continuous cell lines and immune ascitic fluid pools in arbovirus detection. Res. Virol., 1992; 143: 417-422.

[18] Zanotto, P.D., Gould, E.A., Gao, G.F., Harvey, P.H. and Holmes, E.C. Population dynamics of flaviviruses revealed by molecular phylogenies. Proc. Nat. Acad. Sci., 1996; 93(2): 548-553.

[19] Haddow, A.D., Schuh, A.J., Yasuda, C.Y., Kasper, M.R., Heang, V., Huy, R., Guzman, H., Tesh, R.B. and Weaver, S.C., Genetic characterization of Zika virus strains: geographic expansion of the Asian lineage. PloS. Negl. Trop. Dis., 2012; 6(2): e1477.

[20] Faye, O., Freire, C.C., Iamarino, A., Faye, O., de Oliveira, J.V.C., Diallo, M. and Zanotto, P.M. Molecular Evolution of Zika Virus during Its Emergence in the $20^{\text {th }}$ Century. PloS. Negl. Trop. Dis., 2014; 8(1): e2636.

[21] Dick GWA, Kitchen SF, Haddow AJ, Zika Virus: (I) Isolation and serological specificity. Trans. R. Soc. Trop. Medd. Hyg., 1952; 46(5); 509-520.

[22] Berge $\mathrm{T}$ (editor). International catalog of arboviruses and edition, Washington DC. National Institute of allergy and infection diseases and center for disease central. 1975.

[23] Lee, V.H. and Moore, D.L. Vectors of the 1969 yellow fever epidemic on the Jos Plateau, Nigeria. Bulletin of the World Health Organization, 1972; 46(5): 669.

[24] Marchette, N.J., Garcia, R. and Rudnick, A., Isolation of Zika virus from Aedes aegypti mosquitoes in Malaysia. Am. J. Trop. Med. Hyg., 1969; 18(3), 411-415.

[25] Smithburn, K.C., Neutralizing antibodies against certain recently isolated viruses in the sera of human beings residing in East Africa. J. Immunol., 1952; 69(2): 223-234.

[26] Fagbami AH, Zika Virus infection in nigeria: virological and seroepidemiological investigations in oyo state. J. Hyg. (Lond). 1979; 83(2): 213-219.

[27] Jan C, Languillat G, Ranaudet J, Robin Y, A serological survey of arboviruses in Gabon. Bull.Sciences de Pathalogie Exotique et de ses filiales. 1974; 71(2): 140-146.

[28] McCrae, A.W.R. and Kirya, B.G., Yellow fever and Zika virus epizootics and enzootics in Uganda. Transactions of the Royal Society of Tropical Medicine and Hygiene, 1982; 76(4): 552-562.
[29] Saluzzo, J.F., Gonzalez, J.P., Herve, J.P. and Georges, A.J., [Serological survey for the prevalence of certain arboviruses in the human population of the south-east area of Central African Republic (author's transl)]. Bulletin de la Societe de pathologie exotique et de ses filiales, 1980; 74(5): 490-499.

[30] Monlun, E., Zeller, H., Le Guenno, B., Traore-Lamizana, M., Hervy, J.P., Adam, F., Ferrara, L., Fontenille, D., Sylla, R. and Mondo, M. [Surveillance of the circulation of arbovirus of medical interest in the region of eastern Senegal]. Bulletin de la Societe de pathologie exotique (1990), 1992; 86(1): 21-28

[31] Akoua-Koffi, C., Diarrassouba, S., Benie, V.B., Ngbichi, J.M., Bozoua, T., Bosson, A., Akran, V., Carnevale, P. and Ehouman, A., 2001. [Investigation surrounding a fatal case of yellow fever in Cote d'Ivoire in 1999]. Bulletin de la Societe de pathologie exotique 1990; 94(3): 227-230.

[32] Darwish, M.A., Hoogstraal, H., Roberts, T.J., Ahmed, I.P. and Omar, F. A sero-epidemiological survey for certain arboviruses (Togaviridae) in Pakistan. Transactions of the Royal Society of Tropical Medicine and Hygiene, 1983; 77(4): 442-445.

[33] Olson, J.G. and Ksiazek, T.G., Zika virus, a cause of fever in Central Java, Indonesia. Transactions of the Royal Society of Tropical Medicine and Hygiene, 1981; 75(3): 389-393.

[34] Duffy MR, ChenaTH, Hencock WT, Powees AM, Kool JL, Lanciotti RS, Pretrick M, Marfel M. et al. Zika Virus outbreak on yap island, Fedrated states of micronesi. N. Engl. J. Med., 2009; 360(24): 2536-2543

[35] Oehler, E., Watrin, L., Larre, P., Leparc-Goffart, I., Lastere, S., Valour, F., Baudouin, L., Mallet, H., Musso, D. and Ghawche, F., 2014. Zika virus infection complicated by Guillain-Barre syndrome--case report, French Polynesia, Euro Surveill, 2013; 19(9): 20720

[36] Mlakar, J., Korva, M., Tul, N., Popović, M., Poljšak-Prijatelj, M., Mraz, J., Kolenc, M., Resman Rus, K., Vesnaver Vipotnik, T., Fabjan Vodušek, V. and Vizjak, A., Zika virus associated with microcephaly. N. Eng. J. Med., 2016; 374(10): 951-958.

[37] Campos, G.S., Bandeira, A.C. and Sardi, S.I. Zika virus outbreak, Bahia, Brazil. Emerging infectious diseases, 2015; 21(10): 1885.

[38] Cardoso, C.W., Paploski, I.A., Kikuti, M., Rodrigues, M.S., Silva, M.M., Campos, G.S., Sardi, S.I., Kitron, U., Reis, M.G. and Ribeiro, G.S., Outbreak of exanthematous illness associated with Zika, chikungunya, and dengue viruses, Salvador, Brazil. Emerging infectious diseases, 2015; 21(12): 2274.

[39] Epidemiológica, V., 2005. Ministério da Saúde. Secretaria de Vigilância em Saúde. Ações de Prevenção e.

[40] Schuler-Faccini, L., 2016. Possible Association Between Zika Virus Infection and Microcephaly-Brazil, 2015. MMWR. Morbidity and Mortality Weekly Report, 65.

[41] Broutet, N., Krauer, F., Riesen, M., Khalakdina, A., Almiron, M., Aldighieri, S., Espinal, M., Low, N. and Dye, C., 2016. Zika virus as a cause of neurologic disorders. N. Eng. J. Med. 